\title{
Malaysian Journal of Microbiology
}

\section{Published by Malaysian Society for Microbiology} (In SCEPUS since 2011)

\section{First report of Erwinia psidii associated with papaya dieback disease in Malaysia}

\author{
Wan Ting Chai ${ }^{1}$, Jualang Azlan Gansau ${ }^{2}$, Markus Atong ${ }^{3}$, Jugah Kadir ${ }^{4}$, Evenni Poili ${ }^{5}$ and \\ Khim Phin Chong ${ }^{1}$
}

\author{
${ }^{1}$ Sustainable Palm Oil Research Unit (SPOR), Faculty of Sustainable Agriculture, Universiti Malaysia Sabah, Jalan UMS, \\ 88400 , Kota Kinabalu, Sabah, Malaysia. \\ ${ }^{2}$ Biotechnology Programme, Faculty of Science and Natural Resources, Universiti Malaysia Sabah, Jalan UMS, 88400, \\ Kota Kinabalu, Sabah, Malaysia. \\ ${ }^{3}$ Faculty of Sustainable Agriculture, Universiti Malaysia Sabah, Jalan UMS, 88400, Kota Kinabalu, Sabah, Malaysia. \\ ${ }^{4}$ Department of Plant Protection, Faculty of Agriculture, Universiti Putra Malaysia, 43400, UPM Serdang, Selangor Darul \\ Ehsan, Malaysia. \\ ${ }^{5}$ Tuaran Agriculture Research Centre, Department of Agriculture Sabah, P.O. Box. 102, 89208, Tuaran, Sabah, \\ Malaysia. \\ Email: chongkp@ums.edu.my
}

Received 30 June 2016; Received in revised form 9 August 2016; Accepted 12 August 2016

\begin{abstract}
Aims: The outbreak of papaya dieback disease in Malaysia has been reported since 2003. Several reports previously confirmed Erwinia papayae and E. mallotivora to be the causal pathogen of the disease. The present study aimed to identify the causal pathogen of papaya dieback disease in Sabah.

Methodology and results: Infected tissues of papaya dieback disease were collected from Kota Belud, Sabah and the bacterium responsible for the infection was isolated on Luria Bertani (LB) agar and nutrient agar (NA). Seven isolates with similar characteristics to Erwinia were isolated, subjected to the Koch's Postulates test and then identified using $16 \mathrm{~S}$ rRNA sequencing technique. The bacterium was identified to be $E$. psidii, a common pathogen to guava but not to papaya.

Conclusion, significance and Impact of study: This report serves as the first confirmation of the E. psidii in causing papaya dieback disease, suggesting the possibility of this bacterium undergoing host shifting to papaya plants and the possibility of becoming another major threat to the papaya industry in the future.
\end{abstract}

Keywords: Papaya dieback disease, Koch's Postulates, Erwinia psidii, Sabah, 16S rRNA

\section{INTRODUCTION}

Papaya is one of the major tropical fruits consumed in the world. It is estimated that Malaysia produces 35,600 tonnes papaya each year where 22,200 tonnes are exported to other parts of the world (FAOSTAT, 2013). The increase in global demand for papaya has led to improvement in papaya quality and the production in Malaysia. However, the production of papaya is threatened as the industry is affected by various diseases (Sew et al., 2008), such as the outbreak of the bacterial dieback disease in 2003. The papaya dieback disease had spread to six states in Malaysia by 2006 and had caused an annual loss of USD 58 million (Maktar et al., 2008). The disease is capable of destroying the papaya trees and cause yield loss.

Years of research confirmed that papaya dieback disease is caused by Erwinia papayae (Maktar et al., 2008) and E. mallotivora (Noriha et al., 2011) in Malaysia. Further investigation carried out by Noriha et al. (2011) had confirmed that E. mallotivora is the main causal agent of this deadly disease in Peninsular Malaysia. However, there is not much information on this disease in Sabah until it was detected recently in Kota Belud. This paper will serve as the first report on the identification of a bacterium not usually associated with papaya disease, namely the $E$. psidii, in causing papaya dieback disease.

\section{MATERIALS AND METHODS}

\section{Isolation of papaya dieback causal pathogen from infected tissue}

Infected papaya samples (leaves, fruits and stems) were collected from several orchards in Kota Belud, Sabah. Symptoms of infection observed on the trees in the orchard include greasy, water-soaked lesions and spots on leaves, petioles, trunks and fruits. A small piece of the diseased tissue was collected from the edge of a significant lesion of the respective parts of the tree using a 
sterile blade. Few drops of sterile distilled water was placed on the tissue before it was grinded with a sterile glass rod. The resulting suspension was then streaked on Nutrient Agar (NA) and Luria-Bertani (LB) Agar using a sterile-flamed wire loop (Falkow et al., 2006; Maktar et al., 2008). After streaking, the petri dishes were incubated at $30{ }^{\circ} \mathrm{C}$ and examined for 2-3 days (Bradbury, 1970). Erwinia spp. is a slow-growing bacterium; therefore Petri dishes with growth on the first day of incubation were discarded. The morphology of the successfully isolated microbes were carefully compared with the descriptions of Erwinia spp. as reported in previous studies (Maktar et al., 2008; Noriha et al., 2011). Hyaline bacterial colonies were obtained on LB agar after $48 \mathrm{~h}$ of incubation at $30^{\circ} \mathrm{C}$. On the media, the colonies were generally mucoid and domed and varied in color from white to cream.

\section{Gram-staining test}

A loopful of water was placed on the slide. A sterile loop was used to pick up a very small amount of possible bacteria culture on agar and mixed them into the water on the slide. The mixture was dispersed over the center of the slide and the slide was dried by normal evaporation of the water. The slide was passed over the flame of Bunsen burner to fix the bacteria smear to the slide. The smear was flooded with crystal violet and let stand for $1 \mathrm{~min}$ and gently rinsed with distilled water. The smear was flooded with Gram's iodine and let stand for $1 \mathrm{~min}$. The smear was gently washed with distilled water. The smear was decolorized using 95\% ethanol by applying drop by drop for 5 to $10 \mathrm{sec}$. The smear was rinsed immediately with distilled water before flooded with safranin to counter-stain and let for $45 \mathrm{sec}$. The slide was blot dry and observed under light microscope (Bisen, 2014).

\section{Koch's Postulates test}

Seven Gram-negative samples deemed possibly to be Erwinia isolates were selected to be further tested with Koch's Postulates test. Three months-old papaya seedlings were used for inoculation. The seedlings were first grown in polybags sized 8 inches $\times 12$ inches filled with peat moss as the medium and watered daily. Before inoculation of the seedlings, the seven isolates were maintained on Luria-Bertani (LB) agar for $48 \mathrm{~h}$. A sterile needle was used to injure the stems of the seedlings. A sterile cotton bud was used to transfer the bacteria inoculums from the LB to the injured area. Four other papaya seedlings were inoculated with sterile distilled water to serve as control. The seedlings were monitored and checked every two days for any formation of papaya dieback disease symptoms. Observation ended when the seedlings perished. The bacteria were re-isolated from the diseased and perished seedlings onto LB plates and the morphology of the isolates were examined to fulfil the last stage of the Koch's Postulates (Bradbury, 1970). The chosen isolates were grown in LB liquid culture and maintained in $20 \%$ glycerol stock at $-80^{\circ} \mathrm{C}$.

\section{Molecular identification of the causal pathogen of papaya dieback disease}

Pathogens re-isolated from infected seedlings after the Koch's Postulates test and which had the same morphology descriptions to the original pathogen culture were selected for genomic identification. Genomic DNA was extracted using DNeasyTM Blood and Tissue Kit (Qiagen). PCR amplification was performed in a $25 \mu \mathrm{L}$ reaction using thermostable Taq Polymerase in Mastercycler $\AA$ Personal thermal cycler (Eppendorf). The reaction mixture consisted of $1 \times$ PCR buffer; $5 \mu \mathrm{L}$ Promega Green Go Taq Flexi buffer, $4 \mu \mathrm{L} 4.0 \mathrm{mM} \mathrm{MgCl}$, $0.5 \mu \mathrm{L}$ dNTPs, $0.5 \mu \mathrm{L}$ of forward and reverse primers, 0.2 $\mu \mathrm{L}$ Taq Polymerase, $1.5 \mu \mathrm{L}$ of bacterial genomic DNA template and MiliQ water. The amplification reaction was carried out with the following cycling conditions: initial denaturation for $5 \mathrm{~min}$ at $95^{\circ} \mathrm{C}$, followed by 35 cycles of $30 \mathrm{sec}$ at $95^{\circ} \mathrm{C}, 30 \mathrm{sec}$ at $56^{\circ} \mathrm{C}$ and $1 \mathrm{~min} 30 \mathrm{sec}$ at 72 ${ }^{\circ} \mathrm{C}$ and a final extension for $10 \mathrm{~min}$ at $72{ }^{\circ} \mathrm{C}$. The PCR product was run on a $1 \%$ agarose gel. The PCR product was then sent to First Base Laboratory (Selangor, Malaysia) for DNA cloning and sequencing. The gene sequences were later used as query sequences in nucleotide BLAST database for identification. The region of 16S rRNA V4-V6 were targeted (partial 16S rRNA Sequence) for Erwinia species identification and amplicon size was estimated $600 \mathrm{bp}$.

\section{Growth characteristics study}

Growth characteristics of the isolated Erwinia were studied in triplicates. The bacteria culture was incubated at $28-30{ }^{\circ} \mathrm{C}$ for $24 \mathrm{~h}$. The cultures were transferred to a $100 \mathrm{~mL}$ fresh LB broth to obtain uniform cell type and reincubated again at the same temperature for another $24 \mathrm{~h}$. Three $100 \mathrm{~mL}$ conical flasks with fresh LB broth were prepared and a loopful of the culture was used to inoculate each of the flasks. The optical density (OD) reading of the culture was obtained every hour using a spectrophotometer at $600 \mathrm{~nm}$ until the reading remained constant. To calculate the colony forming unit (CFU) of Erwinia culture, $1 \mathrm{~mL}$ of the inoculated LB broth was serial diluted in $9 \mathrm{~mL}$ sterile distilled water and plated out. The plates were allowed to set and were incubated at $28^{\circ} \mathrm{C}$ for 24 - 48 h. CFU was counted after the incubation.

\section{RESULTS}

\section{Isolation of causal pathogen}

There were seven possible causal pathogen isolates collected from different papaya tissues from Kota Belud, Sabah. All possible isolates were Gram-negative. The colonies of the bacteria were light cream to cream colour on NA (Figure 1A) and Luria-Bertani agar (Figure 1B) but pink when inoculated on MacConkey agar (Figure 1C). The result of the gram staining is illustrated in Table 1. 

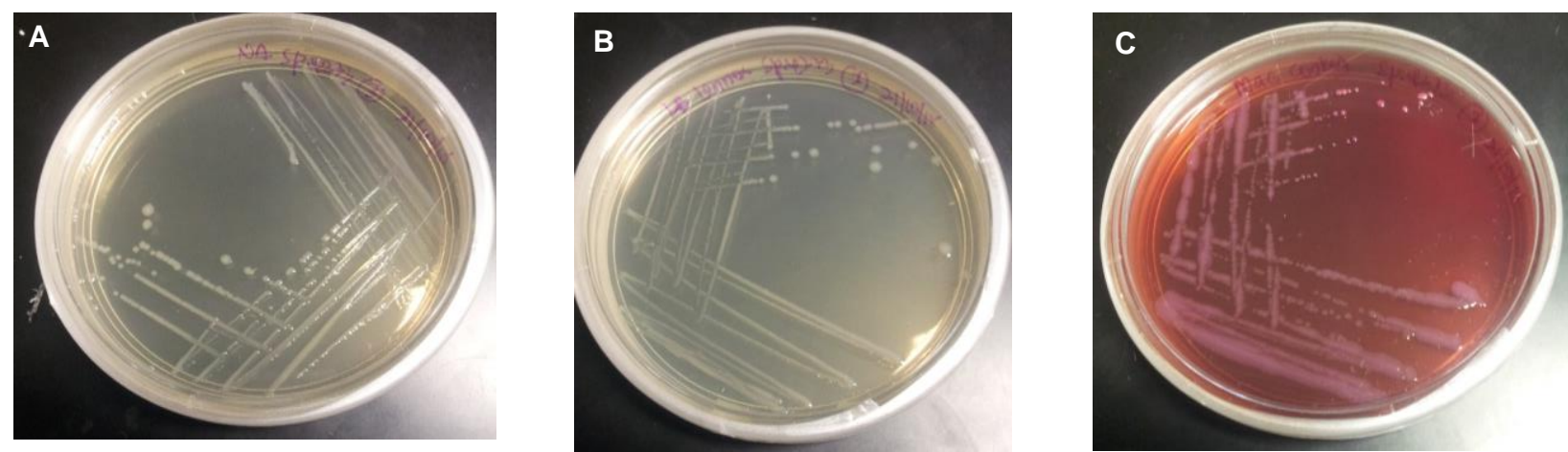

Figure 1: Bacteria colonies of sample Sp4273 on different agars. A, Cream colour, round and smooth colonies were grown on nutrient agar (NA); B, Colonies showed lighter cream colour on Luria-Bertani (LB) agar compared to the previous plate; C, Pink, round bacteria colonies on MacConkey agar.

Table 1: Gram-staining for 7 isolates collected from papaya infected trees in Kota Belud,Sabah.

\begin{tabular}{cc}
\hline Pathogen code & Gram-Staining \\
\hline F17pk210 & Negative \\
F17pk15 & Negative \\
Sp4273 & Negative \\
F17pk39 & Negative \\
S9R2 (stem) & Negative \\
S9R2 (leaf) & Negative \\
F15pk210 & Negative \\
\hline
\end{tabular}

\section{Koch's Postulates test}

The Koch's Postulates test was conducted using three months-old papaya seedlings. Each treatment was performed in four replicates. Papaya dieback symptoms were observed with seedlings inoculated with isolates Sp4273, S9R2 (stem) and S9R2 (leaf). All three isolates showed the same symptoms of infection on papaya seedlings. The symptoms of the infection started as soon as $24 \mathrm{~h}$ post-inoculation, as the injured areas showed water-soaked lesions with dark green colour stem compared to healthy stems (Figure 2A). Observations of these water-soaked lesions in subsequent days showed the infections spreading, followed by drying out and shrinkage. The shrinkage caused the stem to bend, and the plant finally perished. Seedling's leaves showed discolouration symptom. Younger leaves started to turn yellowish instead of dark green colour on day 3 postinoculation (Figure 2B). Dark green to brown colour lesions were found as it developed along the vein of the leaves, which subsequently dried out. The infected leaves would detach from the petioles at the later stage of infection. The seedlings perished 9 days post-inoculation (Figure 2C). The bacteria were re-isolated from the infected seedlings and the colonies showed the same morphology and characteristics as Erwinia spp.
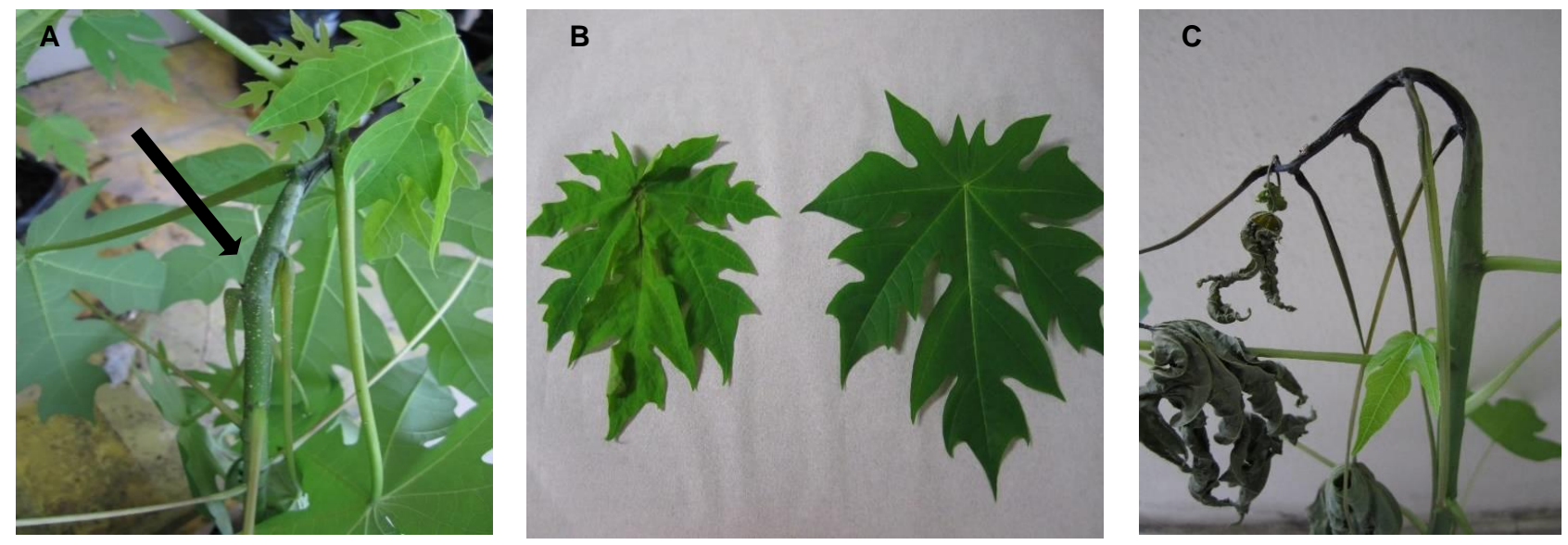

Figure 2: Symptoms of Papaya Dieback Disease. A, Infection caused water-soak lesions (arrow) on the stem and bending; B, Infected papaya leaf (left) turned to yellowish compared to the healthy leaf (right); C, The infection caused mortality at the later stage of infection. 


\section{Pathogen identification}

The isolates S9R2 and Sp4273 were chosen for further molecular identification based on their ability to infect the seedlings. Both isolates had similar base pair sizes, which were approximately $601 \mathrm{bp}$ (Figure 3). From the BLAST analysis, query sequence for sample S9R2 and sample Sp4273 showed high nucleotide identity similarity (99\%) to E. psidii LMG7039 (accession number: NR104569) (Tables 2 and 3 )

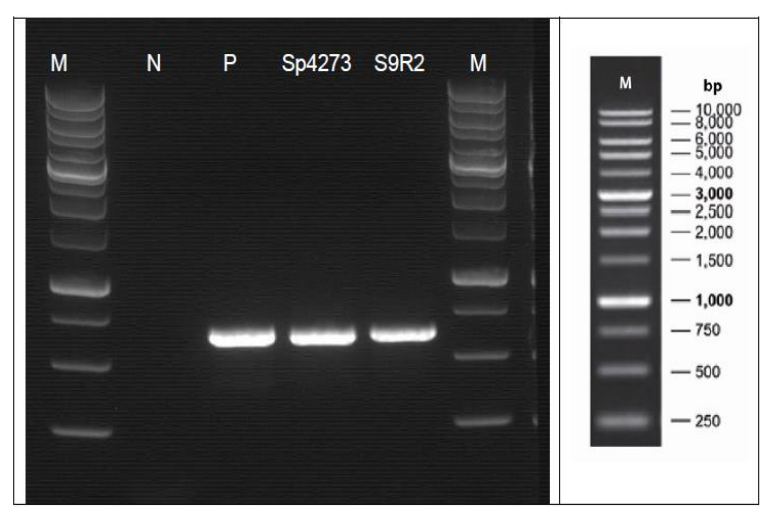

Figure 3: The size of PCR products for isolates Sp4273 and S9R2 in base pairs. $M$ is ladder, $N$ is negative control (without DNA) and $P$ is a positive control (DNA from $E$. coli).

\section{Growth characteristics study}

The growth curve in $\log _{10} \mathrm{CFU} / \mathrm{mL}$ of the $E$. psidii culture over $48 \mathrm{~h}$ incubation is shown in Figure 4 . The bacterium entered the exponential phase after $3 \mathrm{~h}$ of incubation and had a long stationary phase until it reached the death phase after $36 \mathrm{~h}$ of incubation.

\section{DISCUSSION}

This is the first report of E. psidii causing papaya dieback disease in Malaysia. E. psidii was first described by Rodrigues et al. (1987) in São Paulo, Brazil as the pytopathogen causing the dieback disease in Psidium guajava (guava). The pathogen causes rotting in the branches, flowers and fruits of the guava plant. According to Teixeira et al. (2009), E. psidii is one of the most important pathogen due to phytosanitary problems of guava cultivation in Brazil. The pathogen caused a drastic reduction in production when there no effective control measure as taken. To confirm the ability of E. psidii in causing infection to papaya, the pathogen, was inoculated on three-months-old papaya seedlings. The papaya dieback disease symptoms started to develop on the stem of the seedlings and were spread to the leaves. According to Noriha et al. (2011), the bacterium E. mallotivora invades plants through open wounds in the field, colonizes and moves through the plant vascular system. This could possibly be the mechanism of infection for E. psidii, which caused symptoms of the dieback disease in the leaf veins and stems in the papaya seedlings. The Koch's postulates test further confirmed the infection with common symptoms of the disease such as water-soaked lesions on stems and leaves, which led to necrotic and eventual destruction of the plant. The symptoms may have developed after E. psidii travelled along the xylem vessels and subsequently penetrated into the parenchyma intercellular spaces. As the vascular system was attacked by the bacterium, the transportation of essential nutrient and water would be blocked, thus affecting the plant survivability and eventually leading to plant death (Oh and Beer, 2005).

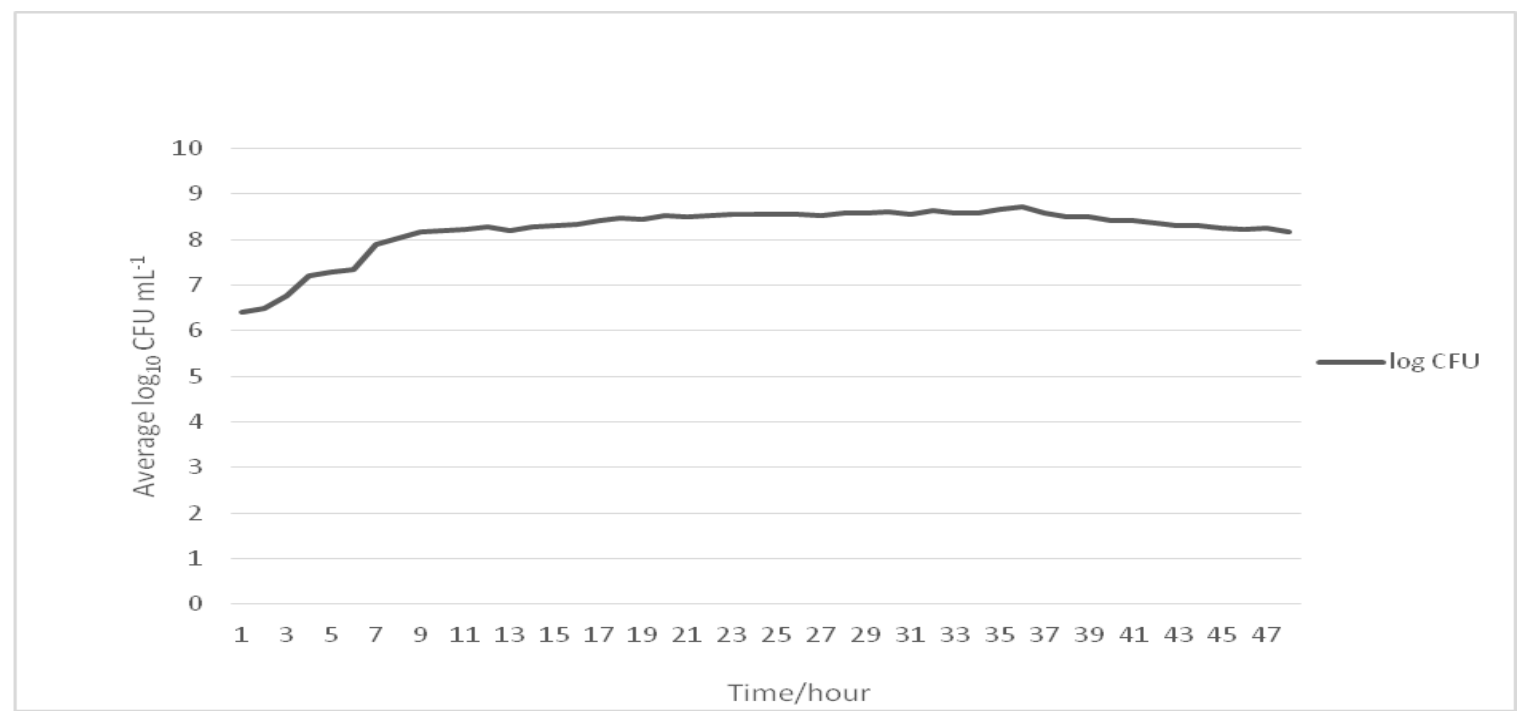

Figure 4: The growth curves of Erwinia psidii over $48 \mathrm{~h}$ of incubation. 
Table 2: Top ten hits from nBLAST analysis from NCBI, where the 16S rRNA sequence of sample S9R2 was sent as the query sequence. Note this isolate had $99 \%$ of similarity to E. psidii strain LMG7039.

\begin{tabular}{|c|c|c|c|c|c|c|}
\hline Description & $\begin{array}{l}\text { Max } \\
\text { score }\end{array}$ & $\begin{array}{l}\text { Total } \\
\text { score }\end{array}$ & $\begin{array}{l}\text { Query } \\
\text { cover }\end{array}$ & $\begin{array}{l}\mathrm{E} \\
\text { value }\end{array}$ & Identity & Accession \\
\hline $\begin{array}{l}\text { E. psidii strain LMG } 703916 \text { S ribosomal RNA gene, partial } \\
\text { sequence }\end{array}$ & 1059 & 1059 & $99 \%$ & 0.0 & $99 \%$ & $\begin{array}{l}\text { NR } \\
104569.1\end{array}$ \\
\hline $\begin{array}{l}\text { E.psidii srain LMG } 7034 \text { 16S ribosomal RNA, partial } \\
\text { sequence }\end{array}$ & 1052 & 1052 & $99 \%$ & 0.0 & $99 \%$ & $\begin{array}{l}\text { NR } \\
044979.1\end{array}$ \\
\hline $\begin{array}{l}\text { Klebsiella pneumoniae subsp. Pneumoniae MGH } 78578 \\
\text { strain ATCC } 700721 \text {; MGH } 78578 \text { 16S ribosomal RNA, } \\
\text { complete sequence }\end{array}$ & 1032 & 1032 & $99 \%$ & 0.0 & $98 \%$ & $\begin{array}{l}\text { NR } \\
074913.1\end{array}$ \\
\hline $\begin{array}{l}\text { Pantoea dispersa strain LG } 260316 \text { S ribosomal RNA gene, } \\
\text { partial sequence }\end{array}$ & 1032 & 1032 & $99 \%$ & 0.0 & $98 \%$ & $\begin{array}{l}\text { NR } \\
116755.1\end{array}$ \\
\hline $\begin{array}{l}\text { E. mallotivora strain ATCC } 29573 \text { 16S ribosomal RNA gene, } \\
\text { partial sequence }\end{array}$ & 1032 & 1032 & $99 \%$ & 0.0 & $98 \%$ & $\begin{array}{l}\text { NR } \\
112557.1\end{array}$ \\
\hline $\begin{array}{l}\text { E. mallotivora strain DSM } 456516 S \text { ribosomal RNA gene, } \\
\text { partial sequence }\end{array}$ & 1032 & 1032 & $99 \%$ & 0.0 & $98 \%$ & $\begin{array}{l}\text { NR } \\
041974.1\end{array}$ \\
\hline $\begin{array}{l}\text { K. pneumoniae subsp. Rhinoscleromatis strain R-70 16S } \\
\text { ribosomal RNA gene, partial sequence }\end{array}$ & 1032 & 1032 & $99 \%$ & 0.0 & $98 \%$ & $\begin{array}{l}\text { NR } \\
037084.1\end{array}$ \\
\hline $\begin{array}{l}\text { P. dispersa strain LMG } 260316 S \text { ribosomal RNA gene, } \\
\text { partial sequence }\end{array}$ & 1031 & 1031 & $99 \%$ & 0.0 & $98 \%$ & $\begin{array}{l}\text { NR } \\
043883.1\end{array}$ \\
\hline $\begin{array}{l}\text { E. billing ae Eb661 strain Eb661, } 16 \mathrm{~S} \text { ribosomal RNA, } \\
\text { complete sequence }\end{array}$ & 1029 & 1029 & $99 \%$ & 0.0 & $98 \%$ & $\begin{array}{l}\text { NR } \\
102828.1\end{array}$ \\
\hline $\begin{array}{l}\text { E. billing ae strain LMG } 2613 \text { 16S ribosomal RNA gene, } \\
\text { partial sequence }\end{array}$ & 1029 & 1029 & $99 \%$ & 0.0 & $98 \%$ & $\begin{array}{l}\text { NR } \\
118431.1\end{array}$ \\
\hline
\end{tabular}

Table 3: Top ten hits from nBLAST analysis from NCBI, where the $16 \mathrm{~S}$ rRNA sequence of sample sp4273 was sent as the query sequence. Note this isolate had $99 \%$ similarity to E. psidii strain.

\begin{tabular}{|c|c|c|c|c|c|c|}
\hline Description & $\begin{array}{l}\text { Max } \\
\text { score }\end{array}$ & $\begin{array}{l}\text { Total } \\
\text { score }\end{array}$ & $\begin{array}{l}\text { Query } \\
\text { cover }\end{array}$ & $\begin{array}{l}\mathrm{E} \\
\text { value }\end{array}$ & Identity & Accession \\
\hline $\begin{array}{l}\text { E. psidii strain LMG } 703916 \text { S ribosomal RNA gene, } \\
\text { partial sequence }\end{array}$ & 1050 & 1050 & $99 \%$ & 0.0 & $99 \%$ & $\begin{array}{l}\text { NR } \\
104569.1\end{array}$ \\
\hline $\begin{array}{l}\text { E. psidii strain LMG } 7034 \text { 16S ribosomal RNA, partial } \\
\text { sequence }\end{array}$ & 1043 & 1043 & $99 \%$ & 0.0 & $99 \%$ & $\begin{array}{l}\text { NR } \\
044979.1\end{array}$ \\
\hline $\begin{array}{l}\text { P. dispersa strain LMG } 260316 \text { S ribosomal RNA gene, } \\
\text { partial sequence }\end{array}$ & 1032 & 1032 & $99 \%$ & 0.0 & $98 \%$ & $\begin{array}{l}\text { NR } \\
116755.1\end{array}$ \\
\hline $\begin{array}{l}P \text {. dispersa strain LMG } 260316 \text { S ribosomal RNA gene, } \\
\text { partial sequence }\end{array}$ & 1031 & 1031 & $99 \%$ & 0.0 & $98 \%$ & $\begin{array}{l}\text { NR } \\
043883.1\end{array}$ \\
\hline $\begin{array}{l}P \text {. dispersa strain DSM } 3007316 S \text { ribosomal RNA gene, } \\
\text { partial sequence }\end{array}$ & 1025 & 1025 & $100 \%$ & 0.0 & $98 \%$ & $\begin{array}{l}\text { NR } \\
116797.1\end{array}$ \\
\hline $\begin{array}{l}\text { Plautia stali symbiont } 16 \mathrm{~S} \text { ribosomal RNA, complete } \\
\text { sequence }\end{array}$ & 1023 & 1023 & $99 \%$ & 0.0 & $98 \%$ & $\begin{array}{l}\text { NR } \\
121693.1\end{array}$ \\
\hline $\begin{array}{l}\text { K. pneumoniae subsp. Pneumoniae MGH } 78578 \text { strain } \\
\text { ATCC } 700721 \text {; MGH } 78578 \text { 16S ribosomal RNA, } \\
\text { complete sequence }\end{array}$ & 1023 & 1023 & $99 \%$ & 0.0 & $98 \%$ & $\begin{array}{l}\text { NR } \\
074913.1\end{array}$ \\
\hline $\begin{array}{l}\text { E. mallotivora strain ATCC } 2957316 \text { S ribosomal RNA } \\
\text { gene, partial sequence }\end{array}$ & 1023 & 1023 & $99 \%$ & 0.0 & $98 \%$ & $\begin{array}{l}\text { NR } \\
112557.1\end{array}$ \\
\hline $\begin{array}{l}\text { E. mallotivora strain DSM } 456516 S \text { ribosomal RNA } \\
\text { gene, partial sequence }\end{array}$ & 1023 & 1023 & $99 \%$ & 0.0 & $98 \%$ & $\begin{array}{l}\text { NR } \\
041974.1\end{array}$ \\
\hline $\begin{array}{l}\text { K. pneumoniae subsp. Rhinoscleromatis strain R-70 } 16 S \\
\text { ribosomal RNA gene, partial sequence }\end{array}$ & 1023 & 1023 & $99 \%$ & 0.0 & $98 \%$ & $\begin{array}{l}\text { NR } \\
037084.1\end{array}$ \\
\hline
\end{tabular}


The symptoms caused by E. psidii were not much different compared to E. mallotivora. This could be the reason why the current described species was not detected or reported earlier. There is a big possibility that E. psidii has undergone a host shifting to papaya or the possibility of multi-host infection by this species as the same species was reported to cause dieback disease on Eucalyptus spp. (Coutinho et al., 2011). Introduction of $E$. psidii to the orchard in any way would lead to adaptation and possibly, infection of non-host plants. Many factors could lead to the transmission of this pathogen to the field such as usage of contaminated tools, poor handling of infected plants and planting infected seedlings. Some pests could also play an important role in transferring the pathogen. To date, there is no effective way to control papaya dieback disease. Further investigation and research could be carried out to develop an effective way to prevent and control the disease.

\section{CONCLUSION}

Isolates S9R2 and Sp4273 were identified as E. psidii via $16 S$ rRNA sequencing technique. The isolates were proven to be the causal pathogen of papaya dieback disease in Kota Belud, Sabah via Koch's Postulates. This report served as the first evidence on the potential of $E$. psidii to cause papaya dieback disease in Sabah, Malaysia. However, more information is required in order to control this pathogen in the future.

\section{ACKNOWLEDGMENTS}

The work was supported by the Research Acculturation Collaborative Effort (RACE) grant (RACE0012-ST-2013) from the Ministry of Higher Education Malaysia and Universiti Malaysia Sabah grant (SBK0021-SG-2012).

\section{REFERENCES}

Bisen, P. S. (2014). Laboratory protocols in applied life sciences. CRC Press, India. pp. 711-712.

Bradbury, J. F. (1970). Isolation and preliminary study of bacteria from plants. Pest Articles and News Summaries 26 (4), 632-637.

Coutinho, T. A., Brady, C. L., van der Vaart, M., Venter, S. N., Telechea, N., Rolfo, M., Perez, C. and Wingfield, M. J. (2011). A new shoot and stem disease of Eucalyptus species caused by Erwinia psidii. Australasian Plant Pathology 40, 55-60.

Falkow, S., Rosenberg, E., Schleifer, K. and Stackebrandt, E. (2006). The prokaryotes: Proteobacteria: Gamma Subclass (Vol. 6). SpringerVerlag, New York. pp. 443-450.

FAOSTAT (2013). Food and agriculture organisation for the United Nations - Statistics online database. Available from http://faostat.fao.org [Retrieved on 25 April 2015].

Maktar, N. H., Kamis, S., Mohd Yusof, F. Z. and Hussain, N. H. (2008). Erwinia papayae causing papaya dieback disease in Malaysia. New Disease Reports 17, 4.

Noriha, M. A., Bunawan, H., Redzuan, R. A. and Jaganath, I. B. (2011). Erwinia mallotivora sp., a new pathogen of papaya (Carica papaya) in Peninsular Malaysia. International Journal of Molecular Science 12(1), 39-45.

Oh, C. C. and Beer, S. V. (2005). Molecular genetics of Erwinina amylovora involved in the development of fire blight. FEMS Microbiology Letters 253 (2), 185-192.

Rodrigues, N. J., Robbs, C. F. and Yamashiro, T. (1987). A bacterial disease of guava (Psidium guajava) caused by Erwinia psidii sp. nov. Fitopatologia Brasileira 12, 345-350.

Sew, Y. S., Maheswary, V., Noor Suhana, A., Hayati, A., Zulkifli, A. S. and Umi Kalsom, A. B. (2008). Preliminary study on expressed sequence tags (ESTs) of papaya, pineapple and pummelo. Journal of Tropical Agriculture and Food Science 36(2), 249-257.

Teixeira, A. C. O., Marques, A. S. A and Ferreira, M. S. V. (2009). Low genetic diversity among pathogenic strains of Erwinia psidii from Brazil. Brazil Journal of Microbiology 40(3), 678-684. 